\title{
Land Art as a Means to Negotiate Natural and Cultural Heritage in the United Arab Emirates
}

\author{
Melanie Janet Sindelar
}

DOI:10.21104/CL.2017.2.03

\begin{abstract}
This article examines the practice of Land Art in the United Arab Emirates as a way to negotiate natural and cultural heritage discourses prevalent in the Arab Gulf. It thereby views artworks as cultural statements that possess the enunciatory power to make visible the negotiation and ambiguity inherent in art production. Since the heritage and art industries in the UAE are closely intertwined, heritage discourses have permeated art production and influenced artists' assumptions about the ways in which nature has been, or should be, equated with the nation. The article argues that Land Art can reveal the ambiguities in artists' negotiation of the relation between nature and nation - regardless of the artists' prior intentions for the artwork.
\end{abstract}

Keywords Heritage, Arab Gulf, Land Art, United Arab Emirates, Third Space.

The research for this article was facilitated through the support of the University of Vienna and its Faculty of Social Sciences.

Contact Melanie Janet Sindelar BA MSc, Department of Social and Cultural Anthropology, University of Vienna, Universitätsstraße 7, 4th floor, 1010 Vienna, Austria; e-mail: melanie.sindelar@univie.ac.at.

Jak citovat / How to cite Sindelar, Melanie Janet. (2017). Land Art as a means to negotiate natural and cultural heritage in the United Arab Emirates. Český lid 104: 213-230. doi:http:// dx.doi.org/10.21104/CL.2017.2.03 


\section{Introduction}

Each year in March, the Qasr al Hosn festival takes place in Abu Dhabi. Named after the fort in the middle of the city commonly known as the "symbolic birthplace" of the nation, ${ }^{1}$ the festival showcases Bedouin traditions that have come to dominate national narratives in the United Arab Emirates (UAE). The Qasr al Hosn festival lasts for eleven days, and in 2015 attracted 120,000 visitors. $^{2}$ The Abu Dhabi Tourism and Culture Authority has organized the festival each year since its establishment in 2013. The festival consists of different sections featuring various parts of Emirati cultural heritage and traditions. Five zones show life in the oasis, desert, and sea, complemented by one zone in the fort and another zone dealing with life on Abu Dhabi Island. In the desert zone, one can learn Sadu weaving, a special form of cloth-making certified as a heritage practice by UNESCO,$^{3}$ or drink Emirati coffee, make butter, and learn about falconry.

Many of these heritage practices detail life before oil exploration and industrialization set in. As such, they are closely tied to the natural environment and pre-industrial livelihoods in the region (Abdulla and Al-Naboodah 2001; Bristol-Rhys 2009), including falconry and camel-rearing. The Qasr al Hosn festival, therefore, is in many ways paradigmatic of the heritagization efforts in the UAE in general. Such festivals create a coalescence of cultural heritage and natural heritage, since certain traditions were shaped by and continue to be predicated upon the immediate natural environment. National narratives such as these have also filtered into the UAE's flourishing art scene, which to a large extent remains state-guided. Often, heritage festivals feature Emirati artists and their work. Art produced about local heritage, identity and culture is on the rise - many pieces can be seen, for instance, at specific festivals for local art production. Although the relation between heritage discourses and big state-funded art institutions has begun to be addressed in scholarly research on the Arab Gulf (Exell - Rico 2014; Wakefield 2014), other institutions, initiatives, and actors of the diverse art scene have not yet been examined. In order to fully understand the dynamics of state-sanctioned heritage efforts and their reception and use in the art scene, it is necessary to focus more closely on the individual practices of artists. Within this context of heritage debates and art production in the UAE, this article examines a specific form of art called Land Art. It argues that forms of art dealing with nature can be particularly revealing about inherent assumptions regarding both the relationship between national identity and heritage, and articulations across the

To be found in various media reports, such as El Shoush (2013), or in government related publications, see for instance Al-Awadhi (2013). 
Nature/Culture and Self/Other divides. In making this argument, I approach artworks as cultural statements which have enunciatory capabilities that can reveal inherent assumptions about the relation between nature and culture. The enunciatory capabilities of such cultural statements can open up what postcolonial theorist Homi Bhabha calls the "Third Space" (2004), a space that has the potential to move beyond the Nature/Culture divide, as anthropologist Andre Gingrich (2013) has argued, and a space that can reveal the ambiguities of cultural statements.

The research for this article was conducted in early spring 2015 and 2016 for a total of five months. Methodologically rooted in participant observation, the research included participating in a Land Art workshop, helping with the process of art production for the Artist in Residence Program (A.i.R.) at Art Dubai, an art fair, as well as the analysis of the art works themselves and discussions with the artists. This article is part of a larger, on-going research project examining the role of contemporary art production in UAE national identity building processes.

\section{Land Art}

As an art form, Land Art is closely associated with locality, soil, territory, and the land. In this article, I will examine the art practice of two Emirati land artists, Mohammed Ahmed Ibrahim and Moza Almathrooshi. Although this article only details the work of these two Emirati artists, the UAE's art scene is much more diverse and includes artists from many different countries whose families have settled in the Arab Gulf. In the context of the UAE's art scene, consisting of large-scale museums such as the Guggenheim and Louvre in Abu Dhabi, galleries and art fairs in Dubai, and the Sharjah Biennial, Land Art as a genre and art practice is not as established as other forms of visual art production - such as traditional painting, videos, or conceptual art - although Land Art is related to conceptual approaches in art.

Land Art developed as a movement in the 1960s in the US and was intended as an antidote to over-commercialized forms of art production. Land Art draws from both minimalist and conceptual art, and as is the case elsewhere, in the UAE Land Artists are often known as conceptual artists. The Land Art movement had its official start with the 1968 group exhibition Earthworks in Dwan Gallery, New York. One of the most well-known American Land Artists was Robert Smithson, whose essay, The Sedimentation of the Mind: Earth Projects, drew the attention of the arts community to Land Art. Land Art, for Smithson, was a reaction against the formalism propagated by Greenberg and Co., which according to Boettger was directed against the formalist approach of insularity and self-criticality as a "visual corollary to the idea of scientific progress" and its zealous, even missionary appeal of all-encompassing self-criticality 
(Boettger 2004: 60). Land Art has, therefore, not merely been an environmental intervention, but also a cultural one.

Smithson's ideas on the contextualization of Land Art rest on Lévi-Strauss, whom he read in the 1960s and 70s when The Savage Mind (Lévi-Strauss 1966) was first translated into English and became available to an American audience. For Smithson, anthropological writings such as The Savage Mind may have played a role in the rejection of formalist approaches, since contextualization is key for Land Art practice: "art critics and artists have for a long time considered the shell without the context of the ocean" (Smithson - Flam 1996: 371).

\section{Theoretical Approach}

The objective of this article is to understand how the Nature/Culture divide creates a certain ambiguity in the politics of national narration which affects art production in the Arab Gulf. The present article therefore builds on research on heritage and the arts world in the Arab Gulf. These are not separate fields, but, as I suggested earlier, are closely interconnected. To understand the dynamics of national identity building, it is necessary to examine how such national narratives transcend - or are actively transported into the UAE's art world, since art plays a major role not only for the outward marketing of a state as a global player in the field of the arts, but also for the inward perception of a nation's cultivation of cultural traditions.

Scholarship on Arab Gulf heritagization efforts has progressed substantially in recent years. As one of the earliest contributions, Sulayman Khalaf examined the "newly invented tradition" of camel racing, arguing that camel races "provide the Emirates' political community with a ritually constructed theatre to celebrate its own specific ideology, cultural traditions, and values [...]" (Khalaf 2000: 244). Khalaf's work draws on the Invented Traditions approach (Hobsbawm - Ranger 1983), but unlike Gellner, Khalaf does not seem to believe that "any old shreds and patches would have served" (Gellner 1983: 56), since camels were "once essential to the Badu pastoral life ways" (Khalaf 2000: 243), and newly invented traditions are often predicated upon some traceable historical traditions.

Other early conceptual contributions, as Fibiger (2011) argues, have relied too much on juxtaposing heritage and globalization as counterweights. Yet the integration of local heritage agendas into global heritage discourses and institutions (such as UNESCO) also shifted scholarly perspectives on heritage developments in the Gulf region. When scholars use terms such as "globalized" or "cosmopolitan" heritage, they seem to point more to the strategies of Culture Authorities in the respective countries, rather than focusing on the precise content of narratives. The museums on Saadiyat Island, for instance, attracted much international attention, and, as Wakefield rightly 
argued, served to position Abu Dhabi in the global art world (Wakefield 2014: 104). Yet Wakefield also concludes that the "official heritage discourse, as set out by the Abu Dhabi government, focuses on the Emirate's role as facilitator of cross-cultural exchange" (Wakefield 2014: 104). Although this might be a strategy to advertise and frame heritage efforts internationally, the approach seems to be limited to communication strategies alone. The narratives carried through heritage festivals haven't entered (yet) into a cross-cultural dialogue with the state's many residents and their cultural legacies, but remain entrenched solely in Bedouin traditions, which are framed as the most important Emirati cultural heritage. These traditions are exhibited in state -funded Arab Gulf museums, whose content seems only to speak to nationals (hence, citizens), strategies which are, as Exell and Rico rightly note, "not practices of social inclusion" (Exell - Rico 2014: 9).

National narration focuses exclusively on Emirati heritage, and this is striking since Emiratis make up only a quarter of the overall population. Three-quarters, then, are non-citizens, or as Neha Vora would label them, "impossible citizens" (Vora 2013). Many of them have lived there for generations and have contributed to the economy - but are excluded from formal citizenship. Precisely because national narratives have been state-guided for so long, the right of "Others" - other persons, other enunciations - to narrate the nation must be taken into consideration. Although this article focuses on Emirati artists, there is a diverse artist community living in the UAE with different cultural backgrounds and nationalities. In this article, however, it is argued that the right to narrate the nation - to negotiate heritage - lies within the process of art production itself, even if artists intend entirely different messages. The selection of the artists has come about through two factors: firstly, it seems to be only Emirati artists who have made their mark in Land Art, but secondly, and most importantly, the state's heritage discourses are directed at them more intensively as both artists and citizens.

The right to narrate the nation has been defined by postcolonial theorist Homi Bhabha as "the authority to tell stories, recount or recast histories, that create the web of social life and change the direction of its flow" (Bhabha 2014). A narrative in itself can be value-free, but national narratives, commonly understood, refer to instrumentalized versions of essentialized identity concepts used for specific purposes. The possibility for counter-narratives, in Foucault's sense, can still exist, as can be seen in Bhabha's idea of the right to narrate the nation from subaltern perspectives.

Contrary to the right to narrate, a narrative in itself, according to Bhabha, is the "act of communication through which the recounting of themes, histories and records, is part of a dialogical process that reveals the transformation of human agency" (Bhabha 2014). Such a right to narrate is however, as Bhabha writes, not only a "legal or procedural matter; it is also a matter of aesthetic and ethical form" (Bhabha 2014). It is an enunciatory right. Therefore, 
not only individuals, or groups, or institutions, possess the right and power to narrate; these enunciations can also emanate from different networks (Struve 2013: 184) and from cultural statements. Cultural statements, for Bhabha, are an important medium of expression, a medium that includes artistic processes and expressions. Cultural statements are constructed in a "contradictory and ambivalent space of enunciation” (Bhabha 2004: 55). In other words, they are produced through the space of enunciation. But in which context do enunciations come into being? To Bhabha, the "discursive conditions of enunciation" are constituted by what he calls the Third Space (Bhabha 2004: 55).

In the Third Space, according to Bhabha, "the structure of meaning and reference" becomes an "ambivalent process", thereby destroying the "mirror of representation in which cultural knowledge is customarily revealed as an integrated, open, expanding code" (Bhabha 2004: 54). Bhabha's concept is based on Fredric Jameson's idea of the "Third Space", a concept first coined in the context of Marxian class theory (Struve 2013: 122). Unlike Jameson, however, Bhabha detaches the concept from its former class-theoretical background and further criticizes Jameson's maintenance of dichotomous thinking (Struve 2013: 122). A Third Space, to Bhabha, represents both the general conditions of language and the specific implication of the utterance in a performative and institutional strategy of which it cannot "in itself be conscious"; it therefore enables the "ambivalence in the act of interpretation" (Bhabha 2004: 53).

The intervention by means of such a Third Space lies in its potential to question a "sense of historical identity of culture as a homogenizing, unifying force, authenticated by the originary Past, kept alive in the national tradition of the People" (Bhabha 2004: 54). Bhabha is interested how the idea of a "national culture" becomes a discursive tool taking away the possibility of narration from the marginalized. The Third Space points at inherent ambiguities in essentialized cultural statements. This space, "though unpresentable in itself [...] constitutes the discursive conditions of enunciation that ensure that the meaning and symbols of culture have no primordial unity or fixity" (Bhabha 2004: 55).

Embedded in postcolonial theory, the present article therefore addresses issues of identity, belonging, and diaspora playing crucial roles in a country like the UAE. In turn, this country's leading groups are struggling to celebrate a past that suggests an essentialized cultual concept that leaves little space for other factors. These include transcultural and transnational connections that were cultivated in the Arab Gulf region long before oil was discovered. The Third Space is a useful concept to understand how artists negotiate the Nature/Culture divide in their own artworks. The struggles visible in the artworks between what is understood to be "original" nature, and which kinds of intrusions are understood to be "foreign", can also show, as I hypothesize, the artist's understanding of how nation and nature are linked. In the following ethnographic section I will discuss how artworks function as cultural 
statements, and can, regardless of the context of production or artist, articulate their own enunciatory right to narrate the nation in more ambivalent ways than the artist intended. The Third Space is then opened up precisely through the ambivalences in artworks, but also points at, and makes visible, the ambiguities and potentials of artworks.

\section{Discovering Land Art in the UAE}

The sun was beating down on our backs as we carried stones from one place to another, forming geometrical lines, creating new structures in the wild. We came to the mountainous desert region of Hatta, near the border with Oman, in a minibus which showed its age with every bump on these infrequently maintained roads of the UAE. The place reminded me of TS Eliot's poem The Waste Land, "where the sun beats, and the dead tree gives no shelter, the cricket no relief, and the dry stone no sound of water". The workshop was held in conjunction with the Artists in Residence (A.i.R.) program of Art Dubai, the Arab Gulf's biggest art fair. Art Dubai annually funds a cohort of artists for around six months to produce site-specific works for the fair. Some of the A.i.R. events are held in public, and so I found myself amongst a group of art enthusiasts in the desert of the UAE. The workshop was an introduction to Land Art as practiced by Mohamed Ibrahim.

Mohamed Ahmed Ibrahim belongs to the older generation of UAE artists and was born in Khorfakkhan. ${ }^{4}$ His work has been shown at various instantiations of the Sharjah Biennial in Dubai's neighboring Emirate, as well as biennials in Havana, Dhaka, Cairo, and Venice, and other exhibitions. Some of his work is currently owned by the Qatari Arab Museum of Modern Art, the Sharjah Museum of Modern Art, and the Netherlands-based Sittard Art Center. Mohamed Ibrahim is part of a group of five Emirati artists known as the pioneers in UAE conceptual art, from which Land Art has drawn some of its intellectual and aesthetic premises.

Mohamed Ibrahim started Land Art work in the eighties, before he even started exhibiting at galleries or shows. According to Mohamed, he often went on trips alone and started to take an interest in stones and the landscape. Mohamed told the Artist-in-Residence Curator of Art Dubai 2015, Lara Khaldi, in an interview how it all started: "Once, around 1989, Hassan Al-Sharif and I went on a day trip, and that's when he told me that I was doing Land Art. I did not have any information about Land Art, because here information about art is scarce, there is a shortage of translations on expressionism and paintings” (Khaldi - Ibrahim 2015: 42). At that point, Ibrahim began to research the work of American Land Artists such as Robert Smithson.

4 Khorfakkhan is an enclave of the Emirate Sharjah situated on the Emirate Fujairah's east coast facing the Gulf of Oman. 
The Land Art workshop managed itself without much talk or explanation. We were instructed to search for stones, then carry them to a place and form a quadrangle. Viewed from above, it looked more like stone work than art production. Yet making art is always work. In this case, it was indeed quite some work - especially since we arrived at noon. The geomorphology around Hatta is primarily shaped by red-colored ophiolites, which is former oceanic crust, and a few deep-water sediments. The stones were surrounded by stinging weeds and it was often hard to lift the stones without getting stung. Another participant of the workshop put this into a wider context: "These little miniscule things here in nature are its defense mechanisms”, Moza said, they "don't want us to invade their space". ${ }^{5}$ A few weeks after our trip to Hatta, Mohammed Ibrahim exhibited some of his other work at Art Dubai, where he was an Artist in Residence at the time. He created two pieces, Fresh and Salt and Land Shift.

\section{Fresh and Salt: the Magic of Tying Things Together, by Tying the Land to the Sea}

Fresh and Salt is an artwork consisting of a heap of stones. More precisely, however, stones from the Caspian Sea and corals from Khorfakkhan are tied together with copper wire. To Mohammed, he cancelled out the distance between the origins of these stones by putting them together, a procedure he termed "a large approximation process" (Khaldi - Ibrahim 2015: 48).

The process of tying things together has a specific cultural connotation in the Gulf. In the interview, Mohamed told Lara Khaldi (Khaldi - Ibrahim 2015) of another instance in which he tied stones "to a yellow nylon string that I made in a village here that we call Al-Badiya on the coast of Djerba. I made the work on a mountain that backs onto the village. I tied the stones and went, and of course I photographed them for documentation. After a while, a friend of mine from that village, Rashed Boughazi, said he knew that I had done the work, he said: 'Mohammed, do you know what happened to your work? So I asked him: 'What happened to it?'. That was at the time of change of seasons from spring to summer, i.e. the period from February when you cannot fish. My friend said that the fishermen thought that I had used black magic against them by tying the stones, and thus tying the sea!'

'Magic!?' - Khaldi asked.

'Yes, magic, linked to the sea. They brought a religious man to break the spell and they disentangled the string from each stone. That's the story behind it." (Khaldi - Ibrahim 2015: 47). 
Another artist named Moza confirmed the story. It is indeed the case that "people in this region, the GCC, or specifically in this country think that anything that's tied is a spell". ${ }^{6}$

\section{Shifting Land, Shifting Borders}

Mohammed's second piece for Art Dubai 2015 was called Land Shift. The artwork was placed outside in the gardens of the Jumeirah hotels, where the art fair is hosted each year. The piece consists of an earth-exchange, or land-exchange, between Oman and the UAE. To Mohammed, this artwork is "a way of breaking boundaries, going beyond borders” (Khaldi - Ibrahim 2015: 45). Being an intern at the time, I witnessed how the hotel was reluctant to let its nicely tended grass be disrupted by an artwork, but eventually they found a spot on which both sides could agree, and so earth from an Omani village travelled all the way to an empty plot at the luxurious Madinat Jumeirah Hotel in Dubai. Mohammed hoped that "this work will invoke an exchange between the village and the city as well as between the sea, the coast, and the mountains. So that you'd end up with a hybrid" (Khaldi - Ibrahim 2015: 48).

\section{Flags of Nature - Flags of the Nation}

Another artist who participated in the Land Art workshop of 2015 was Moza Almathrooshi. In fact, the Land Art workshop inspired her to try out Land Art for herself after having worked in the past with natural resources. When I returned to Dubai in 2016, she presented her work at that year's Artist in Residence exhibition, and I had the chance to talk to her. Before participating at A.i.R., Moza held a Sheikha Salama Emerging Artist Fellowship. The eponymous donator provides the foundation with one-year-long funds in partnership with the Rhode Island School of Design, to train students in various art techniques and skills. Moza also obtained a BA in Fine Arts and Creative Enterprises from Zayed University, and has recently worked on curatorial projects and in exhibition management.

Moza's work, exhibited at the Artist in Residence exhibition at Art Dubai 2016, consisted of flags with imprints on rusty poles, which were erected right outside the Mina Salam Hotel on a patch of grass next to a fountain. The flags showed the texture and dimensionalities of rock formations in Mleiha, the desert of Sharjah. The work, called Markings I, transmits for the artist a sense of loss and decay that, according to her, often features in her work. We sat down next to her work to talk about its origins and impacts.

After the workshop Moza contacted Ibrahim again to find out more about Land Art. She felt that she had found both a home for her art practice, and as 
she half-jokingly said, in Ibrahim "it felt like I found my godfather". After the workshop she started her own Land Art practice in Mleiha: "I started to constantly go to the site which is Mleiha, I kept going and going, and I kept having a constant negotiation with the land; how much am I allowed to take from the land? There's already so much been taken away from it; there are so many stone quarries, so many marks, so many fences; the human presence is just overwhelming; previously you would go there to get away, but now you can't if people are just like all over the place ... and not in their own physical body[ily] presence but [in] the things that they leave behind". ${ }^{7}$ Her work is motivated by documenting the way landscapes change, and the human impact on nature.

Her idea for Markings I came from flags that are painted on the mountains in the UAE. Driving to Hatta, one can easily see large flags painted on the mountains. Moza herself questions this practice: "I feel there is a sacredness to the land". That sacredness can be interpreted differently by different people, however. Moza also found murals, for instance, near Ras al Khaimah, that were in fact prayers: "God please save this land", or to be more precise, "Keep this land safe". Moza said, "The sacredness that we have with the land translates into the flag. Whenever we place a flag we are reinforcing how sacred this land is. And it becomes more apparent in nature, where there is less visual pollution." She also told me that more and more fences have started to appear all over the landscape, either to fence in animals, or mark those "eminent projects that are going to start sprawling along in those areas". She paused and looked at me searchingly: "How long do I have with this landscape? Before it shifts"? I had no answer. But the artwork that she created, to her, was a continuation of preserving this landscape.

In order to create the art, Moza went and took photographs of textures and rocks in order to bring the photography of the land onto these white flags. She thereby transferred the marks from the site to a non-site. But again, she reflected, "with the image of these landscapes I was able to create here, what if one day this is all I have left? All I would be able to do is to see it - but never really touch it". ${ }^{8}$ While creating the art, she looked for the right colors to imprint her markings onto the flags. She initially sought colors indigenous to the UAE, and although she says that indigo, saffron, and henna can be found in the UAE, they seem to be imported from India. She went to the market and talked to the elderly ladies there, and all they could tell her about the colors was "we don't know - all we know is that it is imported from India". ${ }^{9}$

For Moza, this interaction put another layer on her flag. It "became such a familiar thing that we don't question, but it is foreign. Yet it became part of our heritage or culture. That's why I placed it as a layer on top of these flags to almost say that we are -", she searched for the right words - "to reference 
this foreign yet familiar layer that is happening on the land itself [too], whether it's the projects that are happening or -" and she paused again and took a deep breath: "...we now drag past these things and do not really question or notice [them]". She looked at me for affirmation: "I mean I don't have anything against residential projects or industry; I have nothing against people having a place to live! Or having a better business or economy or whatever - but it's constantly a question of what is this landscape going to change into? Even with projects of ecotourism, getting people onto the land still shifts the marks and the landscape". ${ }^{10}$

Nature, for Moza, is sacred - and she tries to protect it. When she heard of Ibrahim's artwork of tying things together, she attempted to do the same. "If I do pretend to make a spell and put it [out there], people are not going to go there anymore" - at least that is what she thought. "Then I went [back] there and noticed that people don't even care, they just moved the stones". To Moza, then, in the end, her art is more an intervention on the actions of humans she seeks to "intervene on what people are doing there, more than intervening in the land itself". ${ }^{11}$

\section{Discussion}

Although both the artists that I introduced in this article practice Land Art, they do it in different ways. Mohammed Ibrahim's Land Art directly intervenes and transforms the land, even shifting land from one place to another. He approaches nature as boundless, uncontainable by borders. The approximation of distance, as seen in one of his artworks, can therefore only be done by force. Mohammed's understanding of nature cannot easily be equated to the limits of the nation.

Moza's approach, on the other hand, might be less interventionist, but this might be because she views nature as original, and deems projects made for tourists in the desert to be artificial and unwanted. Her art protests against such interventions; there seems to be in her art a closer equation of nation with nature. Yet her process of art production reveals the problematic character of this initial assumption of the inherent originality and pureness of nature. In her search for colors she had to necessarily approach the marketplace: while the colors might be theoretically indigenous to the UAE, it is now more viable to import them. Therefore, even the Land Art that Moza practices cannot come "purely" from within the UAE's borders, but already enunciates the manifold historical relations the country has set up in the past and still practices today.

10 Interview with Moza Almathrooshi, March 2016.

11 Interview with Moza Almathrooshi, March 2016. 
Moza's work, however, also speaks of an internal struggle; born as a "'90s kid", as she said, she grew up when the construction of Sheikh Zayed road had just begun. The older she grew, the more expansive it became - in our conversation she used it as a metaphor to refer to the ambiguity of her internal struggles. Moza is not the only artist who views with some suspicion the rapid changes to the UAE's landscape after the advent of the first oil explorations. The Emirates quickly became part of a global economy that marches in step with the pace of world financial centers, to which Dubai now belongs as well.

Mohammed Ibrahim's interventions, in Moza's eyes, are more aggressive, but he too has expressed warnings to journalists about the ways the landscape has transformed in the last few years. "The mountain is disappearing" he said. "They make concrete for skyscrapers. They take the mountain and bring it to the city. Maybe the next generation won't even have a mountain anymore" (Jones 2016). Kevin Jones, who interviewed Ibrahim in his Khorfakkhan home, even concluded dramatically: "[...] it is hard not to wonder, driving back to Dubai past the Khorfakkhan port on the E99 - a thankless stretch of road bordered by oil storage tanks as daunting as the dwindling peaks - how far into the mountains Ibrahim will have to retreat to sustain his singular relationship with a primordial nature that is, slowly but surely, vanishing” (Jones 2016).

\section{The Potential of Land Art}

Between sentiments of intervention and the perseverance of nature, Land Artists make visible both changes in the landscape and the ambiguous nature of their artworks as cultural statements. As discussed earlier, I liken these artworks to what Homi Bhabha has called "cultural statements", statements which are constructed through a "contradictory and ambivalent space of enunciation" (Bhabha 2004: 55) - in a Third Space that works as the in-between.

Even if the artworks presented here reference nature, they reference one, as Moza admits, that has seen numerous interventions already, by both natural and cultural processes. It is impossible to produce an artwork through and in a space that has had no contact with any previous cultural, historical or political processes at all. Moza's process of art production reveals, even if not her original intention, the trade ties between India and the UAE. While theoretically these local colors are available, they are imported from India. Whether one wants to call it an aspect of globalization or transnational relations, the UAE's history, trade, and culture remain entangled with other countries. The advertised openness of cities such as Dubai, their multicultural character and welcome of trade stand in direct contradiction to the country's narrow conception of what can count as cultural heritage. Because of trade and openness, however, the UAE's nature has lost its remoteness. In her 
youth, it used to take Moza a day to reach the Hatta mountains, now you can drive large stretches on a highway.

Access to nature has been enhanced for both Emiratis and residents, but also for tourists - the UAE's natural areas, its deserts, mountains, and the sea, have become highly populated tourist destinations in the last few years. Yet tourism has also been a way to diversify the UAE's economy, which has been one of the primary concerns of the UAE government given the approaching post-oil phase (Melotti 2014). Natural heritage, closely linked to cultural heritage, has thus become a threatened resource, something that might soon be more past than present, and as such is celebrated at the Qasr al Hosn festival mentioned at the beginning of this article. Yet heritage festivals, and the commercialization of natural heritage through the display of dying cultural traditions, has a certain appeal to tourist audiences, who would like to dive into a country's authentic "traditions".

These heritage festivals, however, only show a fraction of the nation's overall history and culture, in celebrating only the traditions of the state's citizens. For instance, many of the state's long-term residents have roots in Indian Ocean countries, yet their heritage is not included in these festivals. The production of artworks dealing with the Nature/Culture divide, such as Moza's Markings I, reveal a multitude of familiar yet "foreign" aspects. Such cultural statements point at a cultural diversity, and in so doing have the potential to provide the enunciations that are constructed in a Third Space that works as the intermediary between nature and culture.

These enunciations in a Third Space inherent to cultural statements thereby facilitate the right to narrate. Artworks, through their production and dissemination, can take on a different meaning - they can take on the right to narrate the nation from a different standpoint, one culturally more diverse than currently imagined by the stately and sheikhly authorities. For Mohammed Ahmed Ibrahim, his piece Land Shift even shows a hybridity in which it is hard to tell which patch of land is which anymore, since they can be both at the same time, and points to the artificiality of the borders between Oman and the UAE.

That hybridity is completely absent in the national narratives of the UAE, which portray an essentialized identity rooted in an idealized Bedouin past. Yet artists dealing with precisely such subject-negotiations stumble time and again onto the rich historical connections that have been cultivated with people of other continents and countries. Although art is subsumed within heritage agendas in the UAE's case, it is the former which can challenge essentialized forms of the latter. Its articulations - and enunciations - are to a certain extent hidden: they are not visible to the public that frequents the big statefunded heritage festivals, only to those who visit art fairs. Yet Land Art reveals in its production process that there is no nature untouched, and certainly not one free of different cultural influences. 


\section{Conclusion}

In this article, I argued that Land Art production can reveal both inherent assumptions artists carry as national subjects, and the ambiguous essence of such cultural statements which move between I and Other, Nature and Culture (this is not to suggest that one can be equated with the other). I have thereby adopted Homi Bhabha's term of cultural statements and have used his concept of the "Third Space", through which cultural statements exhibit their inherent ambiguity and multi-vocality. The Third Space is a space of the in-between, one that constitutes a space between Nature and Culture, as well as at its intersections, thereby blurring the boundaries of each. As Bhabha has stated, "the act of interpretation is never simply an act of communication between the I and the You designated in the statement” (Bhabha 2004: 53). Meaning is only produced when these two places - the I and the You, plus other forms of dichotomies - are, as Bhabha states, "mobilized in the passage of the Third Space", one in which the production of meaning is not necessarily a conscious act in itself. It is however precisely this unconscious relation that suggests an "ambivalence in the act of interpretation" (Bhabha 2004: 53).

The UAE's national narratives deal solely with the heritage of Bedouin groups, and bracket out traditions of other groups, including merchants from abroad, and the now large and well-incorporated migrant communities that have found not only a home in the Arab Gulf, but actively contributed to its economic and social flourishing.

\section{Differences in Practice}

The case studies I selected were different in their approaches to Land Art as a practice. In both, however, two factors play a role. The first factor refers to the interventionist nature of Land Art. Land Art is practiced in nature, yet in the process it takes away from nature in order to create something new out of the raw materials found. At its beginnings in the United States of the '60s, Land Art was a way to resist the commodification of art in confined spaces that were "officially" allowed to exhibit art - such as museums, galleries, and similar spaces. Land Art was supposed to resist such places. Since exhibitions can happen everywhere, art cannot and should not be tied to institutionalized places of art production. Yet Land Art has certainly, on both sides of the ocean, been carried to exhibition spaces. This is also the case with the two artists' works presented here. "I feel selfish with Land Art”, Mohammed Ibrahim remarked to art journalist Kevin Jones in their interview. "Just doing it and keeping it out there. The gallerist needs to see it. There is an urgency to see it" (Jones 2016).

This however raises the second typical issue with Land Art: its ephemerality. Land Art often withers away before the audience gets to see it. Sometimes, 
Moza remarked, she couldn't find her own artworks in the desert anymore, since the desert has its own life, and visitors change the landscape in their ways as well. The artworks, in their evanescence, also point to the short-lived character of specifically natural conditions: climate change is often most visible in nature's most extreme conditions, and deserts certainly belong to this category of extreme natural environments. These natural conditions are tied to a way of life that has been sustained over the centuries in formerly remote and hostile places. As such, they have understandably become part of the contemporary celebration of natural and cultural heritage. It is, however, impossible for just one national narrative to fully explain a place - there is always more to it, and artworks dealing precisely with such topics reveal these different narrations. They thereby assume the right to narrate on behalf of, and regardless of, the artist's intentions.

\section{Implications for Further Research}

The central goals of this article have been to examine art in the processes of national identity construction and heritage celebration and to show how it can reveal the negotiable conditions of such celebrations. Such insights force a rethinking of dichotomies that seem to make the current processes of subject formation in the Arab Gulf easily understandable: the dichotomies between wage laborer and master, Indian and Emirati, desert and other forms of heritage. The desert, in fact, is a strange place to be appropriated for the purpose of singular national narratives, since deserts have been seas that were crossed, not only by Bedouins, but by "foreign" traders and travelers, thereby bringing local traditions into contact with other cultures separated by salt and sand seas.

This of course does not mean that dichotomies are not helpful in initially grasping a complex world, but we must go beyond them if we are to live up to a profession that dedicates itself to analyzing the complexities and richness of cultural (and national) identities. Such identities always stand in a dialogue with more than themselves, and as they do so, become more than themselves.

April 2017 


\section{References}

Abdulla, Adnan K. - Al-Naboodah, Hassan (eds.). 2001. On the folklore and oral history of the United Arab Emirates and Arab Gulf countries. Al Ain: Zayed Center for Heritage and History.

Abu Dhabi Tourism and Culture Authority. 2015. Qasr Al Hosn Festival Attracts Nearly 120,000 Visitors in Just 11 Days. Abu Dhabi.

Al-Awadhi, Abdullah. 2013. "Qasr AlHosn: An Inspiring National Heritage". The Emirates Center for Strategic Studies and Research. Retrieved from: http://www.ecssr.ac.ae/ ECSSR/print/ft.jsp?lang=en\&ftId=/ FeatureTopic/Abdullah_AlAwadhi/ FeatureTopic_1650.xml.

Bhabha, Homi K. 2004. The location of culture, Routledge classics. London, New York Routledge.

Bhabha, Homi K. 2014. "The right to narrate". Harvard Design Magazine. [2017-01-25] Retrieved from: http:// www.harvarddesignmagazine.org/ issues/38/the-right-to-narrate.

Boettger, S. 2004. Earthworks: Art in the landscape of the sixties. Berkeley, London: University of California Press.

Bristol-Rhys, Jane. 2009. “Emirati Historical Narratives". History and Anthropology 20: 2: 107-121.

El Shoush, Mai. 2013. "Qasr Al Hosn Festival celebrates 250 years of Emirati history". [2017-02-03] Retrieved from: http:// www.thenational.ae/arts-culture/onstage/qasr-al-hosn-festival-celebrates250-years-of-emirati-history.

Exell, Karen - Rico, Trinidad. 2014. "Introduction: (De)constructing Arabian Heritage Debates". In: Exell, Karen Rico, Trinidad (eds.): Cultural heritage in the Arabian Peninsula: Debates, discourses and practices. Farnham, Surrey, England: Ashgate: 1-18.

Fibiger, Thomas. 2011. “Global DisplayLocal Dismay. Debating "Globalized Heritage" in Bahrain". History and Anthropology 22: 2: 187-202.
Gellner, Ernest. 1983. Nations and nationalism: New perspectives on the past. Oxford: Blackwell.

Gingrich, André. 2013. “Establishing a 'Third Space'? Anthropology and the Potentials of Transcending a Great Divide". In: Hastrup, Kirsten (ed.): Anthropology and Nature. LondonNew York: Routledge: 108-124. Hobsbawm, Eric J. - Ranger, Terence O. 1983. The invention of tradition. Cambridge: Cambridge University Press. Jones, Kevin. 2016. “Mohammed Ahmed Ibrahim. Where I Work". [2017-0123] Retrieved from: http://www. artasiapacific.com/Magazine/98/ MohammedAhmedIbrahim.

Khalaf, Sulayman. 2000. "Poetics and Politics of Newly Invented Traditions in the Gulf: Camel Racing in the United Arab Emirates". Ethnology 39: 3: 243-261.

Khaldi, Lara - Ibrahim, Mohammed A. 2015. "Stones. A conversation between Lara Khaldi and Mohammed Ahmed Ibrahim". In: A.i.R. Dubai, 2. (ed.): Book of doubt. Dubai: Art Dubai: 42-59.

Lévi-Strauss, Claude. 1966. The Savage Mind. London: Weidenfeld \& Nicolson.

Melotti, Marxiano. 2014. “Heritage and Tourism. Global Society and Shifting Values in the United Arab Emirates". Middle East Topics \& Arguments 03: 71-88.

Smithson, Robert - Flam, Jack D. 1996. Robert Smithson, the collected writings, The documents of twentieth-century art. Berkeley: University of California Press. Struve, Karen. 2013. Zur Aktualität von Homi K. Bhabha: Einleitung in sein Werk, Aktuelle und klassische Sozialund Kulturwissenschaftler/innen. Wiesbaden: Springer Fachmedien. United Nations Educational Scientific and Cultural Organization (UNESCO). 2011. "Al Sadu, traditional weaving skills in the United Arab Emirates. Inscribed in 2011 (6. COM) on the List of Intangible Cultural Heritage in Need of Urgent 
Safeguarding". [2017-02-03] Retrieved from: http://www.unesco.org/culture/ ich/en/USL/al-sadu-traditional-weavingskills-in-the-united-arab-emirates-00517. Vora, Neha. 2013. Impossible citizens:

Dubai's Indian diaspora. Durham, London: Duke University Press.
Wakefield, Sarina. 2014. “Heritage, Cosmopolitanism and Identity in Abu Dhabi". In Exell, Karen - Rico, Trinidad (eds.): Cultural heritage in the Arabian Peninsula: Debates, discourses and practices. Farnham, Surrey, England: Ashgate: 99-117.

\section{Land art jako prostředek pro vymezení přírodního a kulturního dědictví ve Spojených Arabských Emirátech}

Tento článek zkoumá, jakým způsobem je land art (krajinné umění) ve Spojených Arabských Emirátech používán při vymezování diskurzů o přírodě a kulturním dědictví rozšířených v Arabském zálivu. Umělecká díla vidí jako kulturní prohlášení, která mají tu moc formulovat a zviditelnit vymezovací proces a mnohoznačnost, jež jsou pro uměleckou tvorbu neodmyslitelné. Jelikož kulturní dědictví a umělecký průmysl jsou a byly v SAE úzce propojeny, diskurzy o kulturním dědictví vždy pronikaly do umělecké tvorby a ovlivňovaly úvahy umělců o způsobu, jakými příroda byla, nebo by měla být, ztotožňována s národem. Tento článek má za to, že land art dokáže odkrýt mnohoznačnost v umělcově vymezení vztahu mezi přírodou a národem bez ohledu na původní účely umělcova díla. 


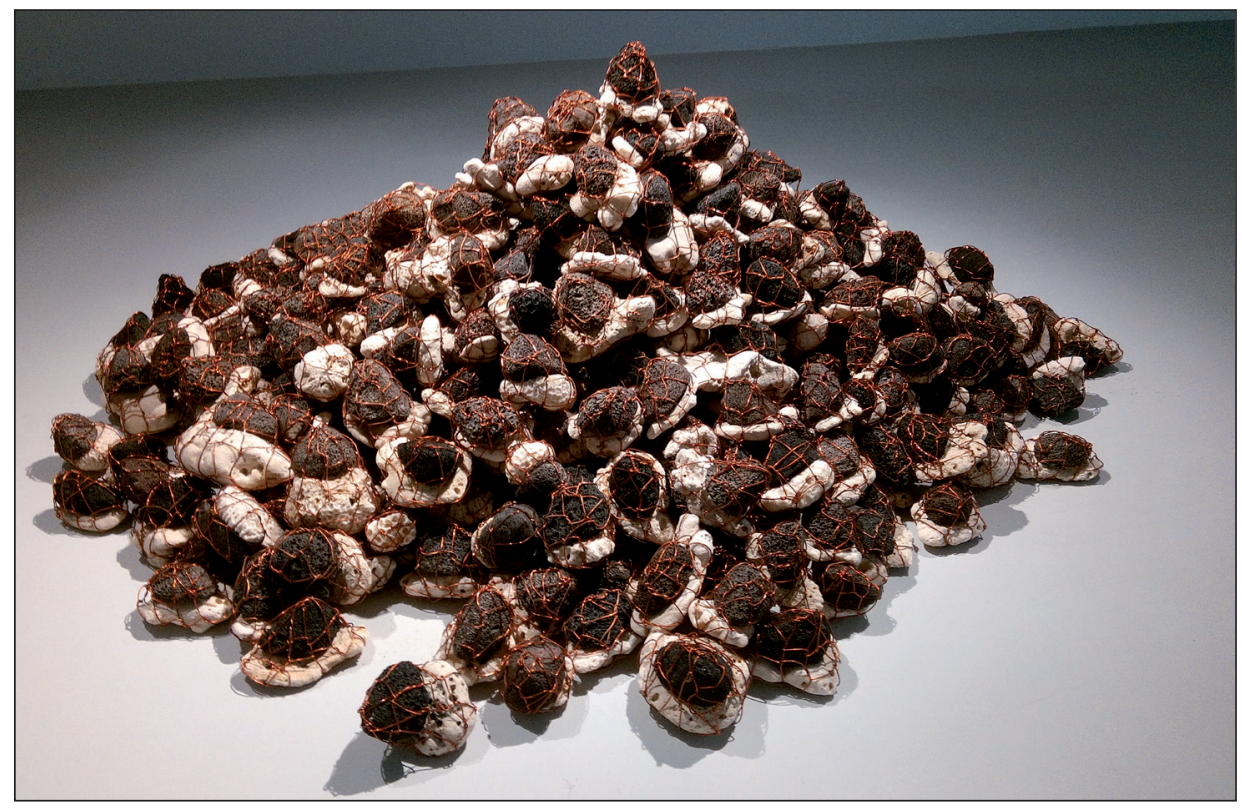

"Fresh and Salt", Mohammed Ibrahim. Photo taken by Melanie Sindelar.

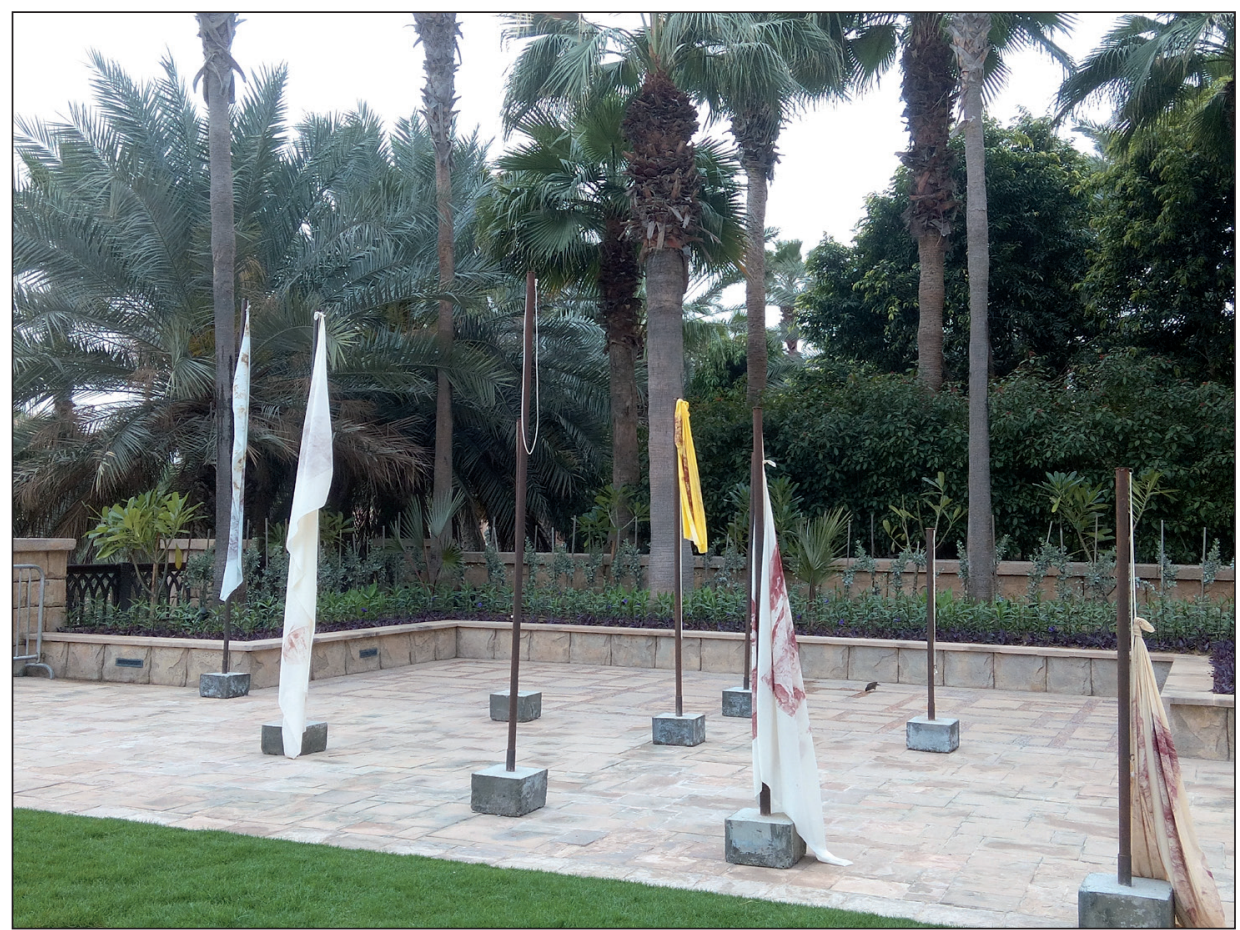

"Markings I", Moza Almathrooshi. Photo taken by Melanie Sindelar. 